Review Article

Lin Yinghua*, Ping Xuelong, Kuang Jiacai, and Deng Yingjun

\title{
Improving the microstructure and mechanical properties of laser cladded Ni-based alloy coatings by changing their composition: A review
}

https://doi.org/10.1515/rams-2020-0027

Received Feb 14, 2020; accepted May 05, 2020

\begin{abstract}
Ni-based alloy coatings prepared by laser cladding has high bonding strength, excellent wear resistance and corrosion resistance. The mechanical properties of coatings can be further improved by changing the composition of alloy powders. This paper reviewed the improved microstructure and mechanical properties of Ni-based composite coatings by hard particles, single element and rare earth elements. The problems that need to be solved for the particle-reinforced nickel-based alloy coatings are pointed out. The prospects of the research are also discussed.
\end{abstract}

Keywords: laser cladding, Ni-based alloy, microstructure, mechanical properties

\section{Introduction}

The commonly used Ni-based alloy powders mainly consist of two series: Ni-B-Si and Ni-Cr-B-Si. The main phases exist in Ni-B-Si alloy coatings are Ni-Si solid solution $(\gamma$ phase), borides ( $\gamma^{\prime}$ phase) and $\gamma-\gamma^{\prime}$ eutectic phase. The coatings are easy to fabricate, which show high toughness, excellent wear resistance, corrosion resistance and high temperature resistance $[1,2]$. The Ni-Cr-B-Si alloy is formed by adding an appropriate amount of $\mathrm{Cr}$ to the Ni-B-Si powder. The phase in Ni-Cr-B-Si alloy coatings is complex. $\mathrm{Cr}$ atoms can react with $\mathrm{C}$ atoms and $\mathrm{B}$ atoms to form carbides and borides, becoming the first strengthening phases of

\footnotetext{
${ }^{\star}$ Corresponding Author: Lin Yinghua: School of Mechanical and Electrical Engineering, Putian University, Fujiang Province, Putian 351100, China; Email: wuzw1960@126.com; lyh351258@126.com Ping Xuelong: Patent Examination Cooperation Tianjin Center of the State Intellectual Property Office, Tianjin 300162, China

Kuang Jiacai, Deng Yingjun: School of Automotive and Mechanical Engineering, Changsha University of Science and Technology, Changsha 410114, Hunan Province, China
}

the cladding layer, which can effectively improve the wear resistance of the metal surface. $\mathrm{Cr}$ atoms can also dissolve in $\mathrm{Ni}$ atoms and act as solid solution strengthening, which can significantly improve the hardness of coatings. Ni based alloy coatings have strong metallurgical bonding, good wear resistance and excellent corrosion resistance. It has broad application prospects in engineering $[3,4]$. The commonly used methods of preparing Ni-based coatings include laser cladding, plasma spraying, TIG and so on.

Laser cladding, known as a promising method of surface engineering, has been widely applied in modification of surface properties. The high energy laser beam is used as the heat source and the alloy powder as the cladding material. The alloy powder and the matrix surface are melted quickly by the radiation of the high energy density laser. After the laser beam removes away, the molten metal solidified rapidly because of the heat conduction of the matrix, thus the cladding layer is completely metallurgic with the matrix, which aiming to improve the surface properties of matrix. At present, the commonly used laser cladding processes are preset powders method and simultaneous powder feeding method. In the preset powders method, the powder is pre-placed onto the substrate surface homogeneously. The laser spot melts the powders and surface of substrate along the set trajectory. After the laser left, the melt pool solidified into coating. The schematic diagram of the laser cladding with the preset powder method is shown in Figure 1. Simultaneous powder feeding method is to send powder to the molten pool while the laser is radiating. The schematic diagram of laser cladding with simultaneous powder feeding method is shown in Figure 2. The coatings obtained by laser cladding have smaller heat affected zone. The coatings have compact structure, good combination with substrate, low porosity and low content of inclusions [5].

The Ni-based coating prepared by laser cladding has a fine grain, dense microstructure, strong metallurgical bonding between the coating and the matrix, high hardness, excellent wear resistance and corrosion resistance. It has been widely used in aerospace, turbines, automo-

əopen Access. (c) 2020 L. Yinghua et al., published by De Gruyter. (Cc) BY 4.0 License 
(a)

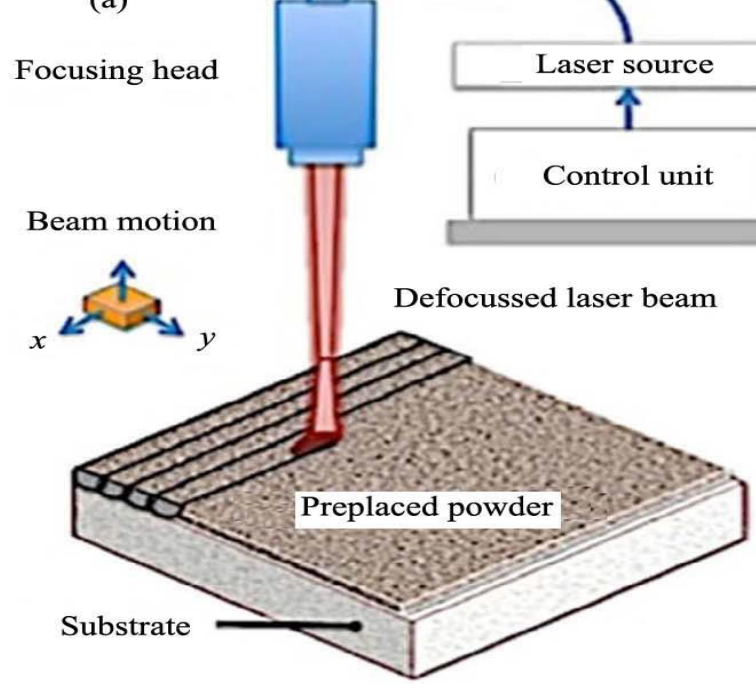

Figure 1: The schematic diagram of laser cladding with preset powder method [7]

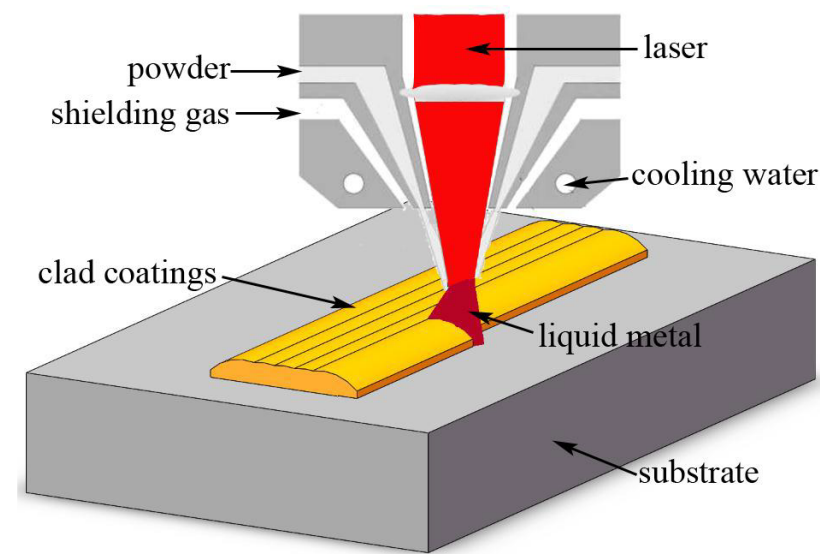

Figure 2: The schematic diagram of laser cladding with coaxial powder feeding

bile mold, piston rods, wearing plates and roller, but in different service environments and engineering components, wear is one of the three main reasons for the failure of engineering materials [6], laser cladding Ni-based coating can be used to repair the worn surface of components, which extends service life and improves mechanical properties. In addition, it is necessary to strengthen the surface, such as for steel, aluminum alloy, etc. However, in conventional NiCrBSi alloy coating, the amount of strengthening phase is less, and the surface properties need to be further improved. Ni-based alloy coatings reinforced by hard particles have high hardness, excellent wear resistance and corrosion resistance, and high temperature oxidation resis- tance. In recent years, many researchers have done a lot of research on the use of strengthening phase particles to improve the performance of $\mathrm{Ni}$ based coatings, and explored the application of $\mathrm{Ni}$ based coatings in engineering. It is expected to provide theoretical and technical support in engineering applications.

\section{Adding hard particles directly}

The direct addition of hard particles is the mechanical mixing of reinforced particles with metal powders, and then the composite materials are prepared by solid state reaction or liquid casting. The advantage is that the phase selection is wide, the preparation is relatively simple, and the particle size is easy to control. The commonly used hard phase particles directly added include: WC, NbC, TiC, $\mathrm{TaC}$ and VC. For a more intuitive comparison of base alloy, cladding methods, hard particles and obtained mechanical properties, the hard particles, Table 1 listed the coatings reinforced by hard particles with direct addition method.

WC particles have the advantages of high melting point and moderate strength and toughness, good compatibility and high bonding strength with Ni-based coatings [8]. Ortiz et al. [9] used to prepare NiCrBSi coatings with different WC addition by laser cladding. It is found that the distribution of WC in the coating is not uniform, and the WC content at the bottom of the coating is higher (as shown in Figure 3). Ma et al. [10] prepared Ni60/WC composite coatings with wide-band laser and circular laser.

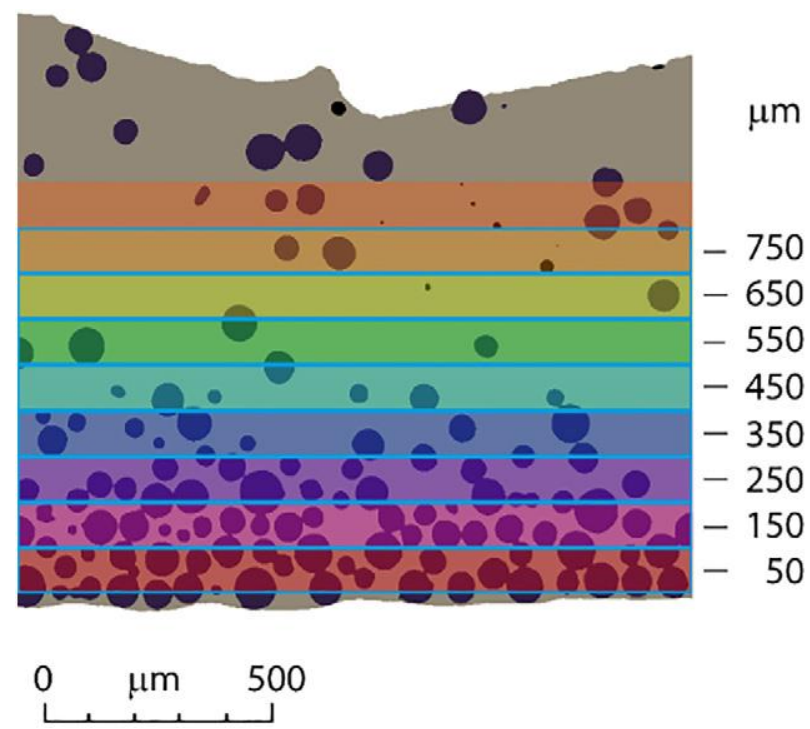

Figure 3: The distribution of WC particles in Ni based coatings [9] 
Table 1: The coatings reinforced by hard particles with direct addition method

\begin{tabular}{|c|c|c|c|c|c|}
\hline Researcher & cladding methods & Substrate & $\begin{array}{c}\text { Hard } \\
\text { particles }\end{array}$ & Base alloy & Mechanical properties \\
\hline $\begin{array}{l}\text { Ortiz et al. [9], Tobar et al. } \\
\text { [11], Li et al. [14] }\end{array}$ & Different content of WC & C45E, AISI 304, H13 & WC & $\begin{array}{l}\text { Metco } 12 \mathrm{C} \text {, } \\
\text { METCO } 16 \mathrm{C} \text {, } \\
\text { Ni60A }\end{array}$ & $\begin{array}{c}\text { The hardness of coatings } \\
\text { was improved }\end{array}$ \\
\hline Ma et al. [10] & $\begin{array}{l}\text { Wide-band laser and cir- } \\
\text { cular laser }\end{array}$ & Q550 steel & WC & $\mathrm{Ni} 60$ & $\begin{array}{l}\text { The hardness and wear } \\
\text { resistance of wide-band } \\
\text { laser coatings was higher } \\
\text { than circular laser coating }\end{array}$ \\
\hline Guo et al. [12] & Preheated the substrate & $1 \mathrm{Cr} 18 \mathrm{Ni} 9 \mathrm{Ti}$ & WC & $\mathrm{NiCrBSi}$ & $\begin{array}{l}\text { The hardness of coatings } \\
\text { was about } 5 \text { times than } \\
\text { substrate, and the wear } \\
\text { resistance increased with } \\
\text { the increase of WC. }\end{array}$ \\
\hline Zhou et al. [13] & $\begin{array}{l}\text { Laser induction hybrid } \\
\text { cladding (LIHC), laser } \\
\text { cladding (LC) }\end{array}$ & $\begin{array}{l}\text { A medium carbon } \\
\text { steel plate }\end{array}$ & wC & $\begin{array}{l}\text { Ni-based } \\
\text { alloy powder }\end{array}$ & $\begin{array}{l}\text { The microhardness and wear } \\
\text { resistance of multi-track } \\
\text { LIHC coating were lower than } \\
\text { multi-track LC coating }\end{array}$ \\
\hline $\begin{array}{l}\text { Da et al. [19], Zhang and } \\
\text { Lei [20] }\end{array}$ & Different content of $\mathrm{Cr} 3 \mathrm{C} 2$ & $\begin{array}{l}\text { Martensitic stainless } \\
\text { steel }\end{array}$ & $\mathrm{Cr}_{3} \mathrm{C}_{2}$ & $\begin{array}{l}\text { Ni-based } \\
\text { alloy }\end{array}$ & $\begin{array}{l}\text { The hardness, wear } \\
\text { resistance and ECW } \\
\text { resistance of coatings were } \\
\text { improved }\end{array}$ \\
\hline Zhang and Zhang [21] & $\begin{array}{l}\mathrm{Ni}+50 \% \quad \mathrm{Cr}_{3} \mathrm{C}_{2}, \\
\mathrm{Ni}+50 \% \mathrm{WC}\end{array}$ & $\begin{array}{l}\text { Martensitic stainless } \\
\text { steel }\end{array}$ & $\begin{array}{l}\mathrm{WC} \\
\mathrm{Cr}_{3} \mathrm{C}_{2}\end{array}$ & $\begin{array}{l}\text { Ni-based } \\
\text { alloy }\end{array}$ & $\begin{array}{l}\text { The ECW rate of both } \\
\text { coatings decreased about } \\
30 \% \text { and } 60 \% \text { than substrate }\end{array}$ \\
\hline $\begin{array}{l}\text { Wilson and Shin [22], Xu } \\
\text { et al. [25] }\end{array}$ & Different content of TiC & $\begin{array}{l}\text { AISI } 1018 \text { steel, AISI } \\
\text { 316L }\end{array}$ & $\mathrm{TiC}$ & $\begin{array}{c}\text { Inconel } 690 \\
\text { alloy, } \\
\text { Inconel } 625\end{array}$ & $\begin{array}{l}\text { The hardness, wear } \\
\text { resistance and corrosion } \\
\text { resistances of coatings were } \\
\text { increased }\end{array}$ \\
\hline Jiang et al. [23] & nano-TiCp & C45 mild steel plates & $\mathrm{TiC}$ & $\begin{array}{c}\text { Inconel } 625 \\
\text { powder }\end{array}$ & $\begin{array}{l}\text { The hardness and modulus } \\
\text { of coatings were higher than } \\
\text { Inconel } 625 \text { substrate }\end{array}$ \\
\hline Meng et al. [27] & Different content of $\mathrm{B}_{4} \mathrm{C}$ & Ti-6Al-4V & $\mathrm{B}_{4} \mathrm{C}$ & $\mathrm{NiCrBSi}$ & $\begin{array}{c}\text { The hardness of coatings } \\
\text { was three times higher than } \\
\text { substrate }\end{array}$ \\
\hline
\end{tabular}

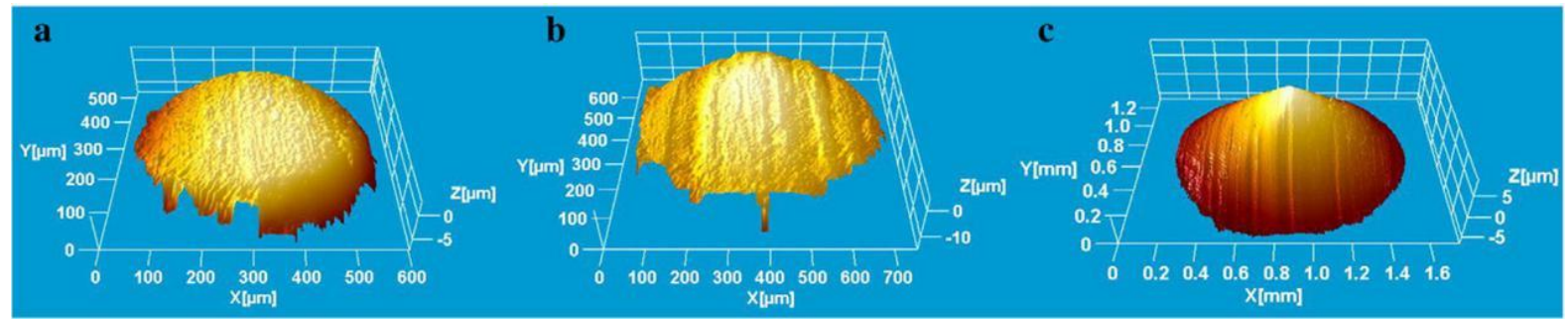

Figure 4: 3D non-contact mapping of worn surface: (a): NiCrBSi coating; (b): NiCrBSi/5\%WC-Ni coating; (c): NiCrBSi/50\%WC-Ni coating [12]

The wear loss of coatings was measured at different sliding distance with a load of $10 \mathrm{~kg}$, and they found the coatings with hard carbides ( $\mathrm{WC}$ and $\mathrm{M}_{23} \mathrm{C}_{6}$ ) and uniform distributed cored eutectic structure improved the hardness and wear resistance. Tobar et al. [11] studied the effect of WC volume fraction on the formation and properties of coatings, dense and crack-free coatings were obtained with less than $50 \mathrm{wt} . \% \mathrm{WC}$, the hardness of coatings were dependent on WC content, which ranged between $600 \mathrm{Hv}$ and $1000 \mathrm{Hv}$. Guo et al. [12] studied the wear resistance of $\mathrm{NiCrBSi}$ and $\mathrm{NiCrBSi} / \mathrm{WC}-\mathrm{Ni}$ coatings with the normal load of $5 \mathrm{~N}$, the 3D non-contact surface mapping of the wear scars is shown in Figure 4, they found the hard WC particles is an effective method to improve the wear resis- 


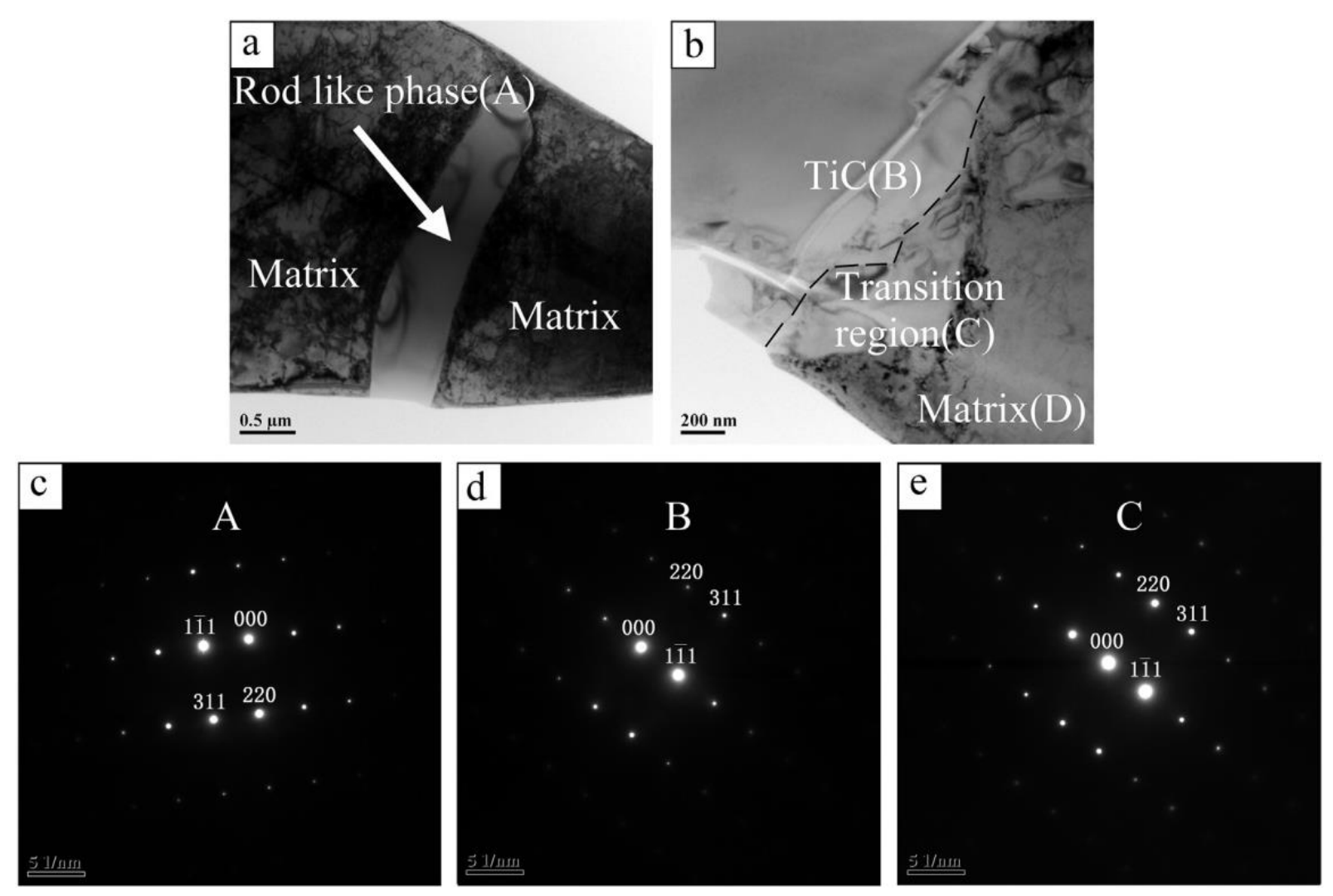

Figure 5: Fine structure of TiC (a): TEM images of rod like phase; (b): TiC, transition region and matrix of composites; (c): SAED patterns of rod like phase; (d): TiC; (e): transition region using zone axis [24]

tance of Ni-based coatings. Zhou et al. [13] studied the effect of laser spots on the performance of WC-NiCrMo coating. It found that the microstructure and mechanical properties of the coatings prepared by circular spots and oval spots were different. The wear resistance of coatings made by multi-track LIHC was lower than multi-track LC under the same laser processing parameters, but the wear resistance improved 1.4 times as the laser scanning speed increase to $1500 \mathrm{~mm} / \mathrm{min}$. Li et al. [14] studied the effect of different WC addition on the microstructure of Ni60A/WC laser cladding layer. It is found that when the addition of WC is $20 \mathrm{wt} . \%$, the main phases of the coating include $\gamma$ (Fe, Ni) dendrites and carbides with intergranular $\mathrm{W}$ rich. When the addition of WC is $33 \mathrm{wt} . \%$, a lot of floc eutectic structure is distributed in the coating. When the addition of WC reaches $50 \mathrm{wt} . \%$, the coating is mainly composed of $\mathrm{M}_{6} \mathrm{C}, \mathrm{M}_{23} \mathrm{C}_{6}$ and $\mathrm{Cr}_{4} \mathrm{Ni}_{15} \mathrm{~W}$. Zang et al. [15] used laser cladding technology to prepare Ni60/WC coatings on $20 \mathrm{Cr}$ steel substrate to improve the hardness and wear resistance of the surface. The phase of Ni60/WC coating is mainly composed of Fe- $\mathrm{Ni}, \mathrm{Cr}_{7} \mathrm{C}_{3}$ and WC. The hard phase WC and $\mathrm{Cr}_{7} \mathrm{C}_{3}$ can improve the hardness and wear resistance of the coating. The hardness of the Ni60-WC coating is $761 \mathrm{Hv}$ (The hardness Ni60A is $607 \mathrm{Hv}$ ), and the wear resistance is $33 \%$ higher than that of the Ni60A coating.

$\mathrm{Cr}_{3} \mathrm{C}_{2}$ is one of the most widely used hard particles to reinforce metal-based coatings. $\mathrm{Cr}_{3} \mathrm{C}_{2}$ reinforced $\mathrm{Ni}$ based coating has high hardness and excellent wear resistance, making it very suitable for the preparation of wearresistant coatings [16, 17]. Yu et al. [18] prepared $\mathrm{Ni}-\mathrm{Cr}_{3} \mathrm{C}_{2}$ composite coatings on the surface of Q235 steel by laser cladding. The grain size of the coating was fine, the microstructure was uniform and dense. The average hardness of the coating reached $1000-1200 \mathrm{Hv}$, the friction coefficient of the coating was about 0.44 , and the friction performance was stable. The combination of $\mathrm{Cr}_{3} \mathrm{C}_{2}$ hard particles and metal matrix can effectively improve the bearing capacity of the cladding layer, which makes the coating have excellent wear resistance. $\mathrm{Ni}-\mathrm{Cr}_{3} \mathrm{C}_{2}$ coatings were prepared by Da et al. [19] to improve the surface properties of stainless steel. $\mathrm{The} \mathrm{Cr}_{3} \mathrm{C}_{2}$ decomposed into $\mathrm{Cr}$ and $\mathrm{C}$ atoms in the molten pool, and $\mathrm{Cr}_{7} \mathrm{C}_{3}$ and $\mathrm{Cr}_{23} \mathrm{C}_{6}$ were formed by the combination of $\mathrm{Cr}$ and $\mathrm{C}$ atoms. The hardness of the Ni$\mathrm{Cr}_{3} \mathrm{C}_{2}$ coating reached $1000-1200 \mathrm{Hv}$, the hardness of the coating was about $400 \mathrm{Hv}$ higher than that of the Ni coating, and the wear resistance increased 1.7 times at the load 
of $60 \mathrm{~N}$. In addition, Zhang and Lei [20] found that the maximum hardness of $\mathrm{Ni}+\mathrm{Cr}_{3} \mathrm{C}_{2}$ coating has arrived to $480 \mathrm{HV}$, and the corrosion resistance of $\mathrm{Ni}+50 \% \mathrm{Cr}_{3} \mathrm{C}_{2}$ coating was about $50 \%$ higher than the substrate. Zhang and Zhang [21] also compared the mechanical properties of $\mathrm{Ni}-\mathrm{Cr}_{3} \mathrm{C}_{2}$ and Ni-WC coatings. The hardness of the $\mathrm{Ni}-\mathrm{Cr}_{3} \mathrm{C}_{2}$ coating is about $300 \mathrm{Hv}$ lower than that of the Ni-WC coating, while the corrosion resistance of $\mathrm{Ni}-\mathrm{Cr}_{3} \mathrm{C}_{2}$ coating is better than that of the Ni-WC coating.

The TiC reinforced metal matrix coating is studied mostly, because TiC presents high melting point, a high stability and hardness. Wilson and Shin [22] prepared the Inconel 690 coating enhanced by $\mathrm{TiC}$ particles by laser direct deposition. The hardness and wear resistance were improved with the $\mathrm{TiC}$ addition, the volume loss rate decreased $42 \%$ with the content of $40 \mathrm{vol} . \% \mathrm{TiC}$ at the load of $2.269 \mathrm{~kg}$. Jiang et al. [23] deposited $5 \mathrm{wt} . \%$ nanoscale $\mathrm{TiC} /$ Inconel 625 coating by laser assisted lumber manufacturing. It found that the hardness and modulus of elasticity of the coating increased by $10.33 \%$ and $12.39 \%$, respectively. Shen et al. [24] used TiC particles to enhance the Inconel 625 coating. The TEM images are shown in Figure 5 , the coating was mainly composed of ( $\mathrm{Ni}-\mathrm{Cr}$ ) solid solution matrix, TiC, and in-situ formed $\mathrm{MC}(\mathrm{M}=\mathrm{Nb}, \mathrm{Ti}, \mathrm{Mo})$. Besides, a transition zone with a width of 3-5 $\mu \mathrm{m}$ existed between the $\gamma$ matrix and the TiC particles. Xu et al. [25] used pure TiC particles to enhance Inconel 625 coatings to improve the surface properties of 316L stainless steel. The results showed that the distribution of $\mathrm{TiC}$ in the coating is very uniform. The hardness of the coating strengthened by $\mathrm{TiC}$ was $330 \mathrm{Hv}$ (220 $\mathrm{Hv}$ without $\mathrm{TiC}$ ), and the tensile strength was $824 \mathrm{MPa}$, which is much better than that of the coating without TiC addition. Besides, the corrosion resistance of the coating also increased with $\mathrm{TiC}$ addition. In addition, some researchers added $\mathrm{Al}_{2} \mathrm{O}_{3}$ [26], $\mathrm{B}_{4} \mathrm{C}$ [27], $\mathrm{SiO}_{2}$ [28] to Ni matrix powder to improve hardness, wear resistance and corrosion resistance of the coating.

\section{In-situ synthesis of hard phase particles}

The in-situ synthesis method is to add elements, then the elements react to form reinforced phase in the process of laser cladding, aiming to enhance the performance of the coating. This provides enough time to match the interface between the phase and the matrix metal, so the bonding strength and compatibility between the reinforced phase and matrix were significantly improved, and the interface was pure. Thus, the mechanical properties of materials have also been correspondingly improved. In addition, the distribution characteristics of the reinforced phase can also be effectively controlled, such as size, morphology and distribution uniformity. Because of these advantages, in situ synthesis is widely used in laser cladding. The carbides and boride reinforcing phases in the coating are mostly prepared by this method [29].

Du et al. [30] used $(\mathrm{Nb}+\mathrm{C}) / \mathrm{Ni} 60$ powder to prepare $\mathrm{NbC}$ particle reinforced Ni60 alloy composite coating by laser cladding on the surface of 45 steel. There were no cracks, pores and other defects in the coating. The main phases in the coatings consist of $\gamma-\mathrm{Ni}, \mathrm{M}_{23} \mathrm{C}_{6}, \mathrm{NbC}$ and $\mathrm{CrB} . \mathrm{NbC}$ was generated by in-situ reaction during laser cladding. The morphology of $\mathrm{NbC}$ mainly consisted of fine granular, irregular block and petal-shaped. The microhardness of the Ni60 alloy coating reinforced by NbC particles reached $1000 \mathrm{Hv}_{0.2}$, which is about $38 \%$ higher than that of pure Ni60 coating. Niu et al. [31] used $\left(\mathrm{Ni60}+\mathrm{Nb}_{2} \mathrm{O}_{5}+\mathrm{C}\right)$ mixed powder as the cladding material. The Ni-based composite coatings reinforced by $\mathrm{NbC}$ were prepared on the surface of A3 steel. The main phases of the Ni60/NbC coating include: $\gamma-(\mathrm{Ni}, \mathrm{Fe})$, carbides and $\mathrm{NbC}$ particles. The average hardness of the Ni60/NbC coating reached about $1200 \mathrm{HV}$, and the wear resistance is 1.5 times higher than that of the Ni60 coating at the load of $300 \mathrm{~N}$.

Cao et al. [32] studied the mechanism of the influence of the morphology of $\mathrm{NbC}$ with different $\mathrm{Nb}$ addition. The results showed that the morphology of $\mathrm{NbC}$ changed from granular to petaloid with the increase of $\mathrm{Nb}$ addition. The alloy powder will melt under the action of laser radiation. At higher temperatures, $\mathrm{Nb}$ and $\mathrm{C}$ combine to form $\mathrm{NbC}$ particles. As the temperature decreases, the molten pool begins to solidify, and a large number of $\mathrm{NbC}$ particles are engulfed by the liquid-solid interface. Due to the low diffusion rate of $\mathrm{Nb}$ and $\mathrm{C}$ atoms in the solid phase, the growth rate of $\mathrm{NbC}$ in the subsequent cooling process is significantly reduced, resulting in a smaller size (hundreds of nanometers), so most of $\mathrm{NbC}$ in the coating is granular. $\mathrm{NbC}$ particles not engulfed by the interface remain in the liquid phase and grow rapidly until the end of solidification. Due to the longer growth period of these $\mathrm{NbC}$ particles, the particles reached a larger size and eventually distributed in the matrix as petals $(5 \mu \mathrm{m})$ or polyhedrons (2 $\mu \mathrm{m})$.

Figure 6 shows the formation sketches of two typical $\mathrm{NbC}$ petals. $\mathrm{NbC}$ has a face-centered cubic structure. Due to the lower interfacial energy of the $\{100\}$ crystal plane family, the growth rate of $\mathrm{NbC}$ in the $<100>$ crystal direction is larger. Therefore, $\mathrm{NbC}$ particles can more easily obtain an octahedral structure, as shown in Figure 6a and 6b. The cooling rate of octahedral corners is large, and the 


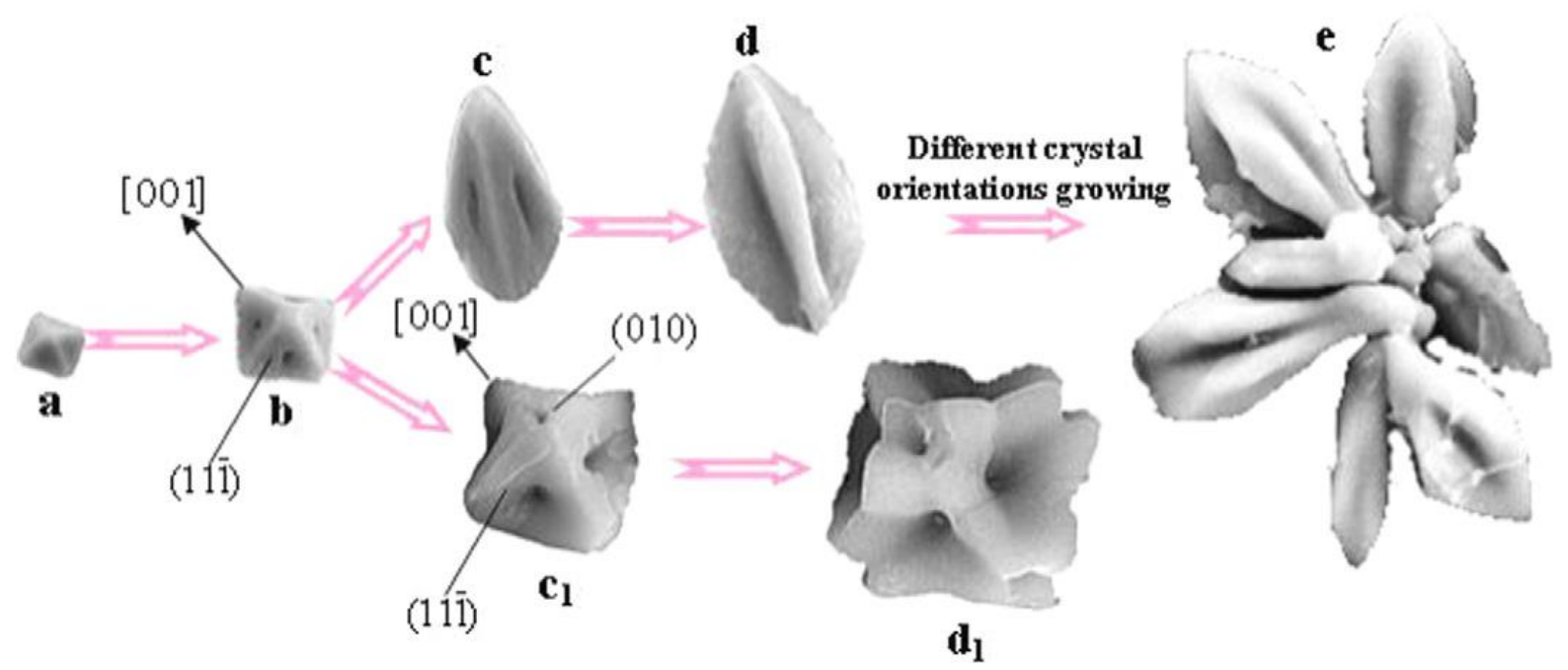

Figure 6: The mechanism of $\mathrm{NbC}$ growth [32]

growth rate of $\mathrm{NbC}$ in these regions is greater than the growth rate of the surface. As a result, pits appeared in the center of the surface. As NbC grows further in the $\langle 100\rangle$ crystal direction, these pits are "stretched" (Figure 6c), which makes the cross-section of a single petal form a cross shape, as shown in Figure 6d. If NbC is grown in different crystal directions, the final morphology will be similar to that shown in Figure 6e. For several NbC grains, the growth rate at the corners of the octahedron is large, so that the $\{010\}$ crystal plane is perpendicular to the $\langle 100\rangle$ direction of the crystal. Also, as shown in Figure $6 c_{1}$, the slower growth rate of $\mathrm{NbC}$ on these planes causes pits to appear in the center of the planes.

$\mathrm{Wu}$ [33] used pure Ti and pure graphite to in-situ synthesize TiC to enhance the Ni-based coating. The average microhardness of the coating reached $1250 \mathrm{Hv}_{0.2}$ and the wear resistance has also been greatly improved at the load of $0.91 \mathrm{~kg}$. Chao [34] used $\mathrm{Ta}_{2} \mathrm{O}_{5}$ and graphite to synthesize $\mathrm{TaC}$ particles in composite coatings to improve the surface properties of the coating. In addition, some researchers produced in-situ $\mathrm{TiB}$ [35], VC [36], $\mathrm{TiB}_{2}$ [37] and TiN [38] particles to improve the performance of coating.

\section{Adding a single element to improve the performance of coating}

$\mathrm{Nb}$ can refine the grains of coatings significantly, and can also reduce the defects such as holes and cracks. The $\mathrm{NbC}$ particles can be generated by in-situ reaction with the carbon atoms in the molten pool in the process of laser cladding. NbC presents a high melting point $\left(3600^{\circ} \mathrm{C}\right)$, high free energy of formation ( $140.7 \mathrm{~kJ} / \mathrm{mol}$ ), high chemical stability, high stability and hardness. NbC possess a similar density $\left(7.79 \mathrm{~g} / \mathrm{cm}^{3}\right.$ [39]) as that of Ni-based coatings, which is beneficial to the distribution uniformity of carbide particles in coatings. Wu et al. [40] produced Ni60A coatings with different $\mathrm{Nb}$ addition. $\mathrm{Nb}$ and $\mathrm{C}$ reacted to form $\mathrm{NbC}$ particles to refine the carbide particles and improve the wear resistance of the coatings. When the addition of $\mathrm{Nb}$ was $6 \mathrm{wt} . \%$, the $\mathrm{NbC}$ phase was found in the coating. Compared with $\mathrm{Nb}$-free coatings, the average hardness decreased by about $300 \mathrm{Hv}_{0.2}$, while the wear resistance increased by nearly 4 times. Cheng et al. [41] prepared $\mathrm{Ni}-\mathrm{Nb}$ composite alloy coatings by laser cladding on 42CrMo substrate by adding Nb elements with different mass fractions in Ni-based coatings. When the amount of niobium added is $10 \mathrm{wt} . \%$, The microstructure of the coating is significantly refined and denser, and the hardness of the coating reaches the highest, which is twice that of the nickel-based alloy coating without niobium.

$\mathrm{Hu}$ et al. [42] investigated the effect of Ti addition on crack and hardness of Inconel 625 coating. With the addition of Ti, the tendency to cracks becomes smaller. The addition of Ti promoted the formation of the ( $\gamma+$ Laves) eutectic phase, and caused the Laves phase to change from a point or short rod morphology to a layered and reticulated shape. When the amount of Ti added is $5 \mathrm{wt} . \%$, The microhardness of the coating is increased by $100 \mathrm{Hv}$ compared with that without Ti. Ma [43] added different mass fraction of Ti to the Ni60/WC composite coating to explore the effect of $\mathrm{Ti}$ on the microstructure and mechan- 

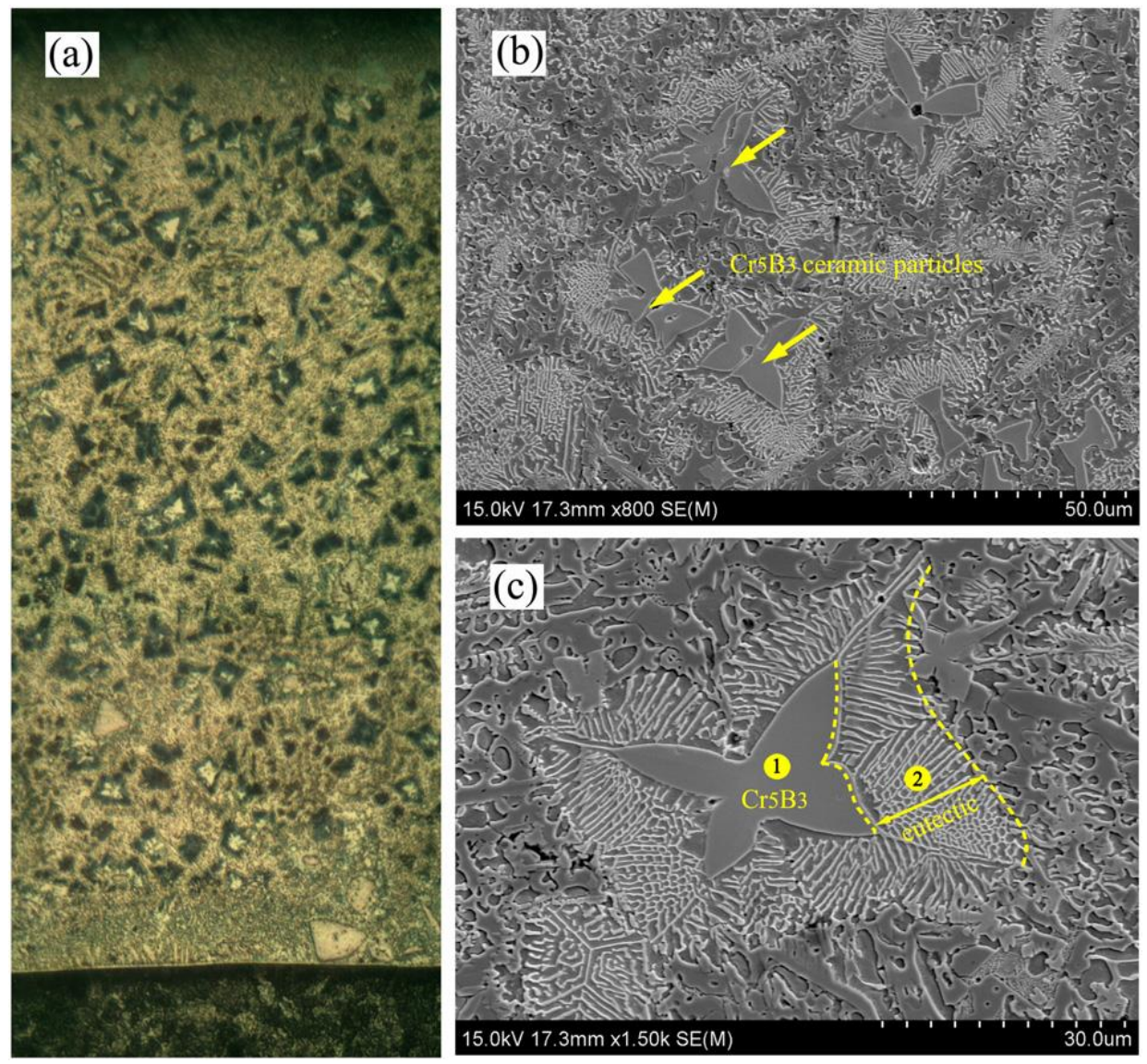

Figure 7: Microstructure of in-situ synthesized ceramic particles in Ni60-20WC coating (a): cross-section; (b): magnified SEM; (c): high magnification microstructure [43]

ical properties of the Ni60/WC coating, and analyzed the hard phase particles synthesized in situ. The microstructure of Ni60-20WC composite coating and Ni60-20WC-2Ti coating is shown in Figure 7 and 8. The results showed that the main ceramic particles in the Ni60/WC composite coating were $\mathrm{Cr}_{5} \mathrm{~B}_{3}$ and $\mathrm{M}_{23} \mathrm{C}_{6}$ (M is $\mathrm{Cr}$ and $\mathrm{W}$ ). After $\mathrm{Ti}$ addition, a large number of netted $\mathrm{TiC}$ appeared in the coating. Besides, the distribution of bulk $\mathrm{Cr}_{5} \mathrm{~B}_{3}$ particles became more homogeneous, and the morphology changed from star shape to uniform square shape. Figure 9 shows the hardness distribution map of Ni60-20WC coating and Ni60-20WC-2Ti coating. It is found that the hardness distribution of coatings was more uniform with $\mathrm{Ti}$ addition, and the wear resistance increased by 2.6 times at the load of $100 \mathrm{~N}$.

Yang et al. [44] prepared $\mathrm{Al}+(\mathrm{Ti}+\mathrm{B} 4 \mathrm{C})$ composite coatings on the surface of AZ91D magnesium alloy, and the effects of $\mathrm{Al}$ on the microstructure and mechanical properties of the coatings were studied. In the process of laser cladding, $\mathrm{Al}_{3} \mathrm{Mg}_{2}, \mathrm{Al}_{12} \mathrm{Mg}_{17}, \mathrm{Al}_{3} \mathrm{Ti}$ and TiC particles were produced by in-situ synthesis. The schematic diagram of compounds is shown in Figure 10. The hardness of the coating reached $348 \mathrm{Hv}$, which is about 5-6 times higher than that of AZ91D. After adding Al, the friction coefficient of the coating decreased, while the wear resistance and corrosion resistance of the coating increased.

Ta is a strong carbide forming element, which is easily reacted with $\mathrm{C}$ to form tantalum carbide (TaC). TaC has high hardness, high melting point (about $3880^{\circ} \mathrm{C}$ ) and high chemical stability, and has excellent chemical resistance, thermal shock resistance and corrosion resistance [45]. Yu et al. [46] added Ta element to NiCrBSi powder, and used in-situ $\mathrm{TaC}$ particles to improve the mechanical properties of NiCrBSi coating. The results showed that the formation of $\mathrm{TaC}$ particles inhibits the formation of $\mathrm{M}_{7} \mathrm{C}_{3}$ and $\mathrm{M}_{23} \mathrm{C}_{6}$, the amount of coarse carbide $\left(\mathrm{M}_{7} \mathrm{C}_{3}\right.$ and $\left.\mathrm{M}_{23} \mathrm{C}_{6}\right)$ decreased, and the grain size is reduced. When the addition of Ta is $5 \mathrm{wt} . \%$, the microhardness of the coating increased by $18 \%$. and the wear resistance also improved. In addi- 

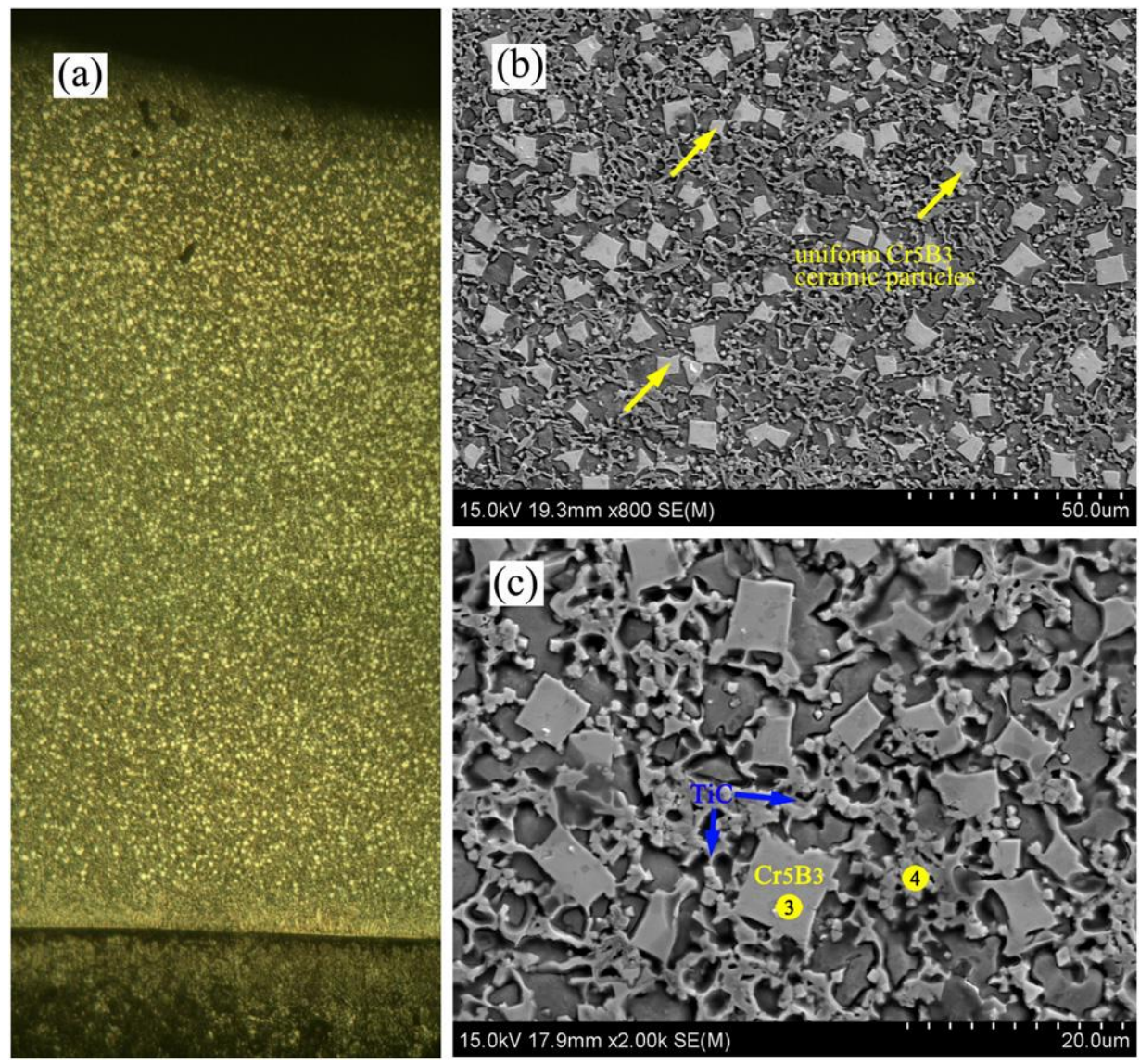

Figure 8: Microstructure of in-situ synthesized ceramic particles in Ni60-20WC-2Ti coating (a): cross-section; (b): magnified SEM; (c): high magnification microstructure [43]
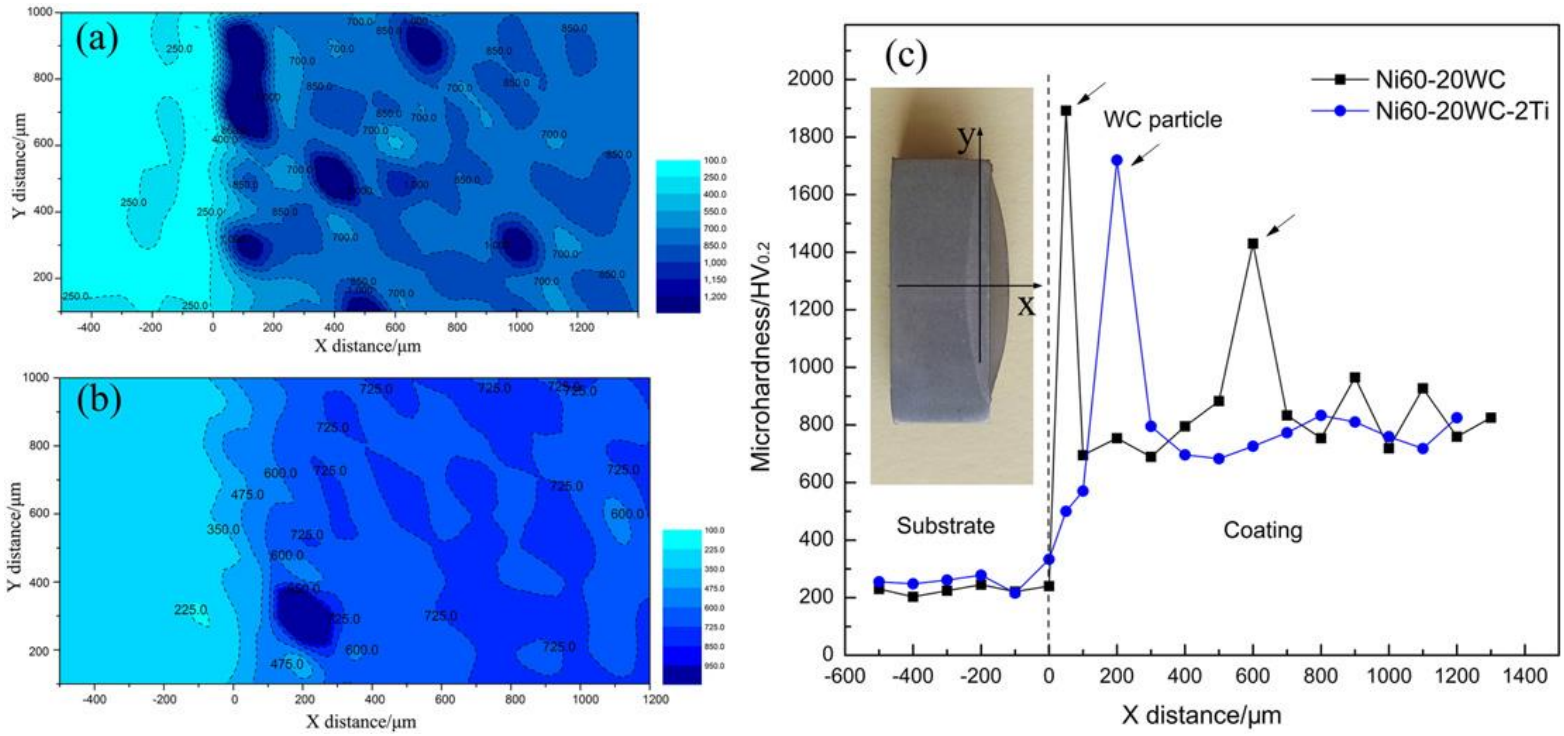

Figure 9: Microhardness test results (a): map distribution in Ni60-20WC coating; (b): map distribution in Ni60-20WC-Ti coating; (c): line profiles of two coatings [43] 


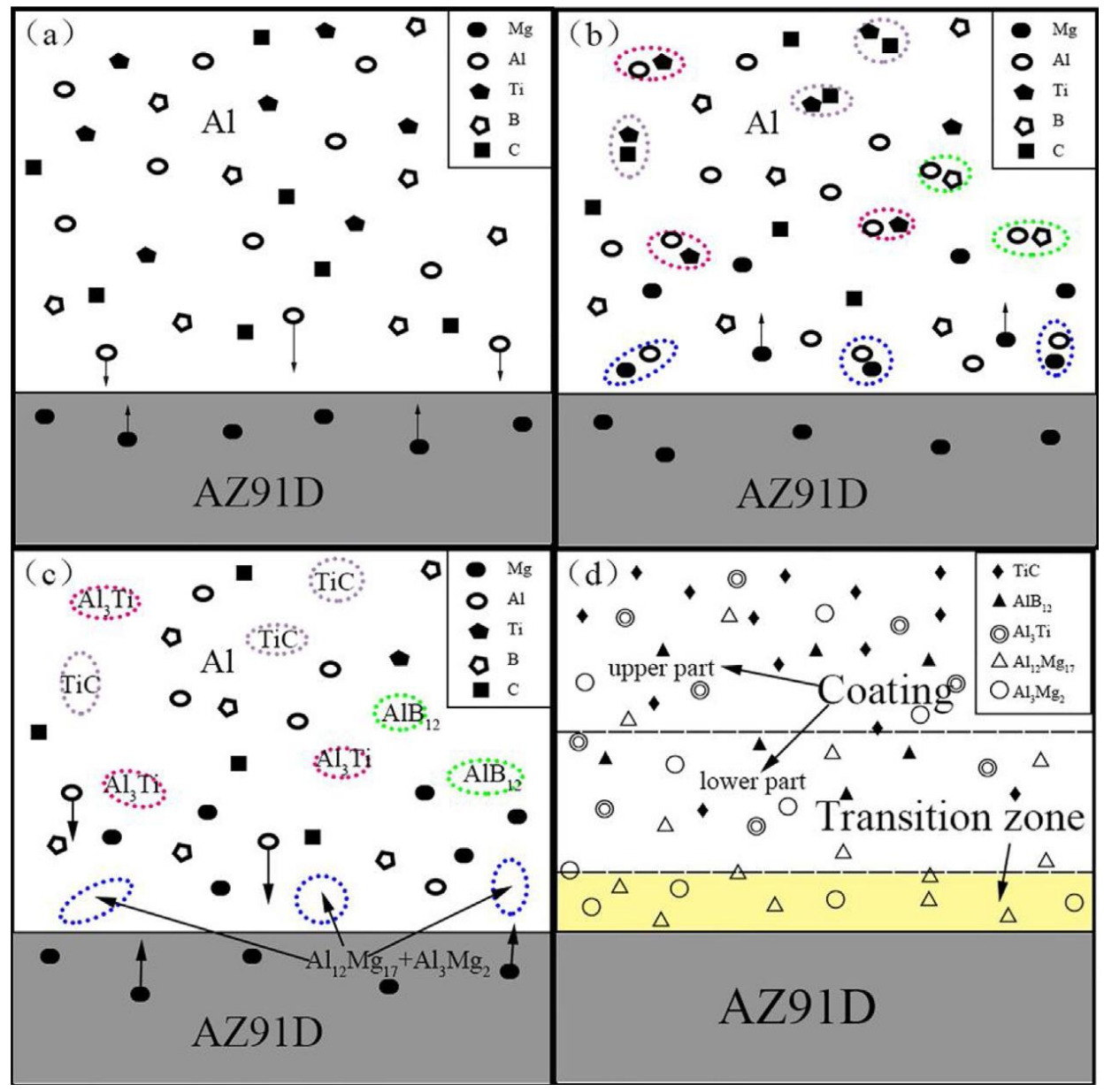

Figure 10: Schematic diagram of compounds [44]

tion, the addition of Ta reduced the crack sensitivity of $\mathrm{Ni}$ based composite coatings.

\section{Adding rare earth elements}

Rare earth elements are a general term for a class of elements and belong to the third group of elements. There are 17 kinds of lanthanide elements, such as lanthanum (La), cerium (Ce), and chemical elements similar to lanthanide. In the electron layer of the rare earth atom, the $4 \mathrm{f}$ electron layer is not filled by electrons. This results in a very active chemical property. The role of rare earth in metallurgy mainly includes: purifying the tissue, reducing the defect rate of the coatings, refining the microstructure, promoting the precipitation of the second phase, and forming the reinforced hard phase.

Zhao et al. [47] prepared Ni-based coatings with $\mathrm{La}_{2} \mathrm{O}_{3}$ addition on the surface of $30 \mathrm{CrMnSiNi2A}$ steel. It is found that La tends to be distributed in dendrites, which limits the secondary growth of dendrites. The microstructure of the coating is more compact, and cracks and holes are not found in the coatings. The hardness of the coating reached 4 times that of the matrix. The friction coefficient was obviously lower than that of the matrix steel, and the wear resistance was nearly 9 times higher than matrix. Wang et al. [48] used laser cladding technology to prepare Ni60 alloy coating with $\mathrm{La}_{2} \mathrm{O}_{3}, \mathrm{Y}_{2} \mathrm{O}_{3}$ and $\mathrm{CeO}_{2}$ addition on $6063 \mathrm{Al}$ surface. The effects of rare earth elements on the microstructure and mechanical properties of Ni based coatings were studied. It has been found that the addition of rare earth elements results in the formation of stable rare earth compounds in the coating. The coatings with $\mathrm{Y}_{2} \mathrm{O}_{3}$ addition appeared $\mathrm{Al}_{4} \mathrm{La}$. The coatings with $\mathrm{Y}_{2} \mathrm{O}_{3}$ addition appear $\mathrm{YAl}_{3}$, AlNiY and $\mathrm{Ni}_{17} \mathrm{Y}_{2}$. CeNi and $\mathrm{Ce}_{3} \mathrm{Ni}_{6} \mathrm{Si} 2$ appear in the coatings with $\mathrm{CeO}_{2}$ addition. After adding rare earth, the microstructure of the coating was more compact and the hardness increased from 200 
$\mathrm{Hv}$ to $350 \mathrm{Hv}$. The wear resistance was significantly improved at the load of $5 \mathrm{~N}$ with the addition of $\mathrm{La}_{2} \mathrm{O}_{3}$ and $\mathrm{CeO}_{2}$.

\section{Conclusion}

The paper reviewed the research progress of improving the microstructure and mechanical properties of Ni-based composite coatings. The hardness, wear resistance and corrosion resistance of coatings can be effectively improved by many ways, such as in-situ synthesis of hard phase particles, adding hard particles directly, single element or rare earth elements, but there are still many problems that still need to be further studied.

1) The direct addition of hard particles can significantly improve mechanical properties of Ni-based coatings. WC, $\mathrm{Cr}_{3} \mathrm{C}_{2}$ and $\mathrm{TiC}$ can effectively improve the hardness and wear resistance of coatings, the corrosion resistance of $\mathrm{Ni}-\mathrm{Cr}_{3} \mathrm{C}_{2}$ coatings is better than that of Ni-WC coatings. However, some researchers found that the particles sometimes are distributed non-uniformly, such as sank or floated in the coatings.

2) The size, morphology and distribution of in-situ $\mathrm{NbC}, \mathrm{TiC}, \mathrm{TaC}, \mathrm{TiB}, \mathrm{VC}, \mathrm{TiB}_{2}$ and $\mathrm{TiN}$ particles can be improved, resulted in the increase of hardness and wear resistance. In situ $\mathrm{NbC}$ consisted of fine granular, irregular block and petal-shaped, and the $<100>$ crystal direction showed a higher growth rate. The wear resistance of $\mathrm{Ni} 60 / \mathrm{NbC}$ coatings improved 1.5 times than that of Ni60 coatings.

3) The addition of $\mathrm{Nb}, \mathrm{Ti}, \mathrm{Al}, \mathrm{Ta}$ elements has effect of refining grain and microstructure, hard particles can be in-situ synthesized by the single element and $\mathrm{C}$ element in the molten pool, which improved the wear resistance of coatings. However, the improvement results of single element on hardness were inconsistent, some researchers found the hardness of coatings decreased with the addition of $\mathrm{Nb}$ or Ti elements.

4) Rare earth $\mathrm{La}_{2} \mathrm{O}_{3}, \mathrm{Y}_{2} \mathrm{O}_{3}$ and $\mathrm{CeO}_{2}$ have the effect of reducing the defect rate, refining the microstructure, promoting the precipitation of the second phase and hard particles. $\mathrm{La}_{2} \mathrm{O}_{3}$ and $\mathrm{CeO}_{2}$ are more effective to improve the hardness and wear resistance of coatings.

5) Laser cladding is a process of non-equilibrium crystallization. The thermodynamics, phase transition kinetics, interfacial behavior and diffusion behavior involved in heating and solidification are needed to be explored. In addition, the relevant standards of laser cladding are not yet perfect, and this technology has not been widely applied in industrial production.

Acknowledgement: The authors would like to thank the financial support for this work from Natural Science Foundation of Fujian Province (No. 2019J01813), Science and Technology Project of Putian (No. 2019GP004).

\section{References}

[1] Sharma, S. P., D. K. Dwivedi, and P. K. Jain. Effect of $\mathrm{La}_{2} \mathrm{O}_{3}$ addition on the microstructure, hardness and abrasive wear behavior of flame sprayed Ni based coatings. Wear, Vol. 267, No. 5-8, 2009, pp. 853-859.

[2] Chaliampalias, D., G. Vourlias, E. Pavlidou, S. Skolianos, K. Chrissafis, and G. Stergioudis. Comparative examination of the microstructure and high temperature oxidation performance of NiCrBSi flame sprayed and pack cementation coatings. Applied Surface Science, Vol. 255, No. 6, 2009, pp. 3605-3612.

[3] Zhang, J., Y. Hu, X. J. Tan, L. Guo, and Q. M. Zhang. Microstructure and high temperature tribological behavior of laser cladding Ni60A alloys coatings on 45 steel substrate. Transactions of Nonferrous Metals Society of China, Vol. 25, No. 5, 2015, pp. 15251532.

[4] Wang, P. Z., J. X. Qu, and H. S. Shao. Cemented carbide reinforced nickel-based alloy coating by laser cladding and the wear characteristics. Materials \& Design, Vol. 17, No. 5-6, 1996, pp. 289-296.

[5] Bansal, A., S. Zafar, and A. K. Sharma. Microstructure and abrasive wear performance of Ni-WC Composite Microwave Clad. Journal of Materials Engineering and Performance, Vol. 24, No. 10, 2015, pp. 1-9.

[6] Wang, S. L., Z. Y. Zhang, Y. B. Gong, and G. M. Nie. Microstructures and corrosion resistance of Fe-based amorphous/nanocrystalline coating fabricated by laser cladding. Journal of Alloys and Compounds, Vol. 728, 2017, pp. 1116-1123.

[7] Quazi, M. M., M. A. Fazal, A. S. M. A. Haseeb, F. Yusof, H. H. Masjuki, and A. Arslan, Effect of rare earth elements and their oxides on tribo-mechanical performance of laser claddings: A review. Journal of Rare Earths, Vol. 34, No. 6, 2016, pp. 550-564.

[8] Paul, C. P., S. K. Mishra, P. Tiwari, and L. M. Kukreja. Solid-Particle Erosion Behaviour of WC/Ni Composite Clad layers with Different Contents of WC Particles. Optics \& Laser Technology, Vol. 50, 2013, pp. 155-162.

[9] Ortiz, A., A. García, M. Cadenas, M. R. Fernández, and J. M. Cuetos. WC particles distribution model in the cross-section of laser cladded NiCrBSi+WC coatings, for different wt\% WC. Surface and Coatings Technology, Vol. 324, 2017, pp. 298-306.

[10] Ma, Q. S., Y. J. Li, J. Wang, and K. Liu. Investigation on coredeutectic structure in Ni60/WC composite coatings fabricated by wide-band laser cladding. Journal of Alloys and Compounds, Vol. 645, 2015, pp. 151-157. 
[11] Tobar, M. J., C. Álvarez, J. M. Amado, G. Rodríguez, and A. Yáñez. Morphology and characterization of laser clad composite NiCrBSi-WC coatings on stainless steel. Surface and Coatings Technology, Vol. 200, No. 22-23, 2006, pp. 6313-6317.

[12] Guo, C., J. M. Chen, J. S. Zhou, J. R. Zhao, L. Q. Wang, Y. J. Yu, et al. Effects of WC-Ni content on microstructure and wear resistance of laser cladding Ni based alloys coating. Surface and Coatings Technology, Vol. 206, No. 8-9, 2012, pp. 2064-2071.

[13] Zhou, S. F., J. B. Lei, X. Q. Dai, J. B. Guo, Z. J. Gu, and H. B. Pan. A comparative study of the structure and wear resistance of $\mathrm{NiCrBSi} / 50$ wt.\% WC composite coatings by laser cladding and laser induction hybrid cladding. International Journal of Refractory Metals and Hard Materials, Vol. 60, 2016, pp. 17-27.

[14] Li, F.Q., X. Y. Feng, Y. B. Chen. Effect of WC content on microstructure of WC/Ni60A laser cladding layer. Chin. J. Las, Vol. 43, No. 1, 2016, pp. 0403009-1-0403009-7.

[15] Zang, C. C., T. Z. Wang, Y. D. Zhang, J. H. Li, H. Zeng, and D. Q. Zhang. Microstructure and Tribological Properties of laser cladding Ni60 + 35WC-Ni coating. Rare Metals, Vol. 39, No. 5, 2019, pp. 385-391.

[16] Matthews, S., B. James, and M. Hyland. High temperature erosion-oxidation of $\mathrm{Cr}_{3} \mathrm{C}_{2}$-NiCr thermal spray coatings under simulated turbine conditions. Surface and Coatings Technology, Vol. 70, 2013, pp. 203-211.

[17] Lou, D. Y., C. L. He, S. Shang, C. Liu, and Q. Cai. Microstructure and performances of graphite scattered $\mathrm{Cr}_{3} \mathrm{C}_{2}-\mathrm{NiCr}$ composites prepared by laser processing. Materials Letters, Vol. 93, 2013, pp. 304-307.

[18] Yu, J., L. Zhu, L. M. Luo, and J. Li. Antifriction properties of laser cladding $\mathrm{Cr}_{3} \mathrm{C}_{2}$-Ni composite coating. Hot Working Technology, Vol. 39, No. 6, 2010, pp. 86-88.

[19] Da, W. Z., T. C. Lei, and F. J. Li. Laser cladding of stainless steel with $\mathrm{Ni}-\mathrm{Cr}_{3} \mathrm{C}_{2}$ for improved wear performance. Wear, Vol. 251, No. 1-12, 2001, pp. 1372-1376.

[20] Zhang, D. W., and T. C. Lei. The microstructure and erosivecorrosive wear performance of laser-clad $\mathrm{Ni}-\mathrm{Cr}_{3} \mathrm{C}_{2}$ composite coating. Wear, Vol. 255, No. 1-6, 2003, pp. 129-133.

[21] Zhang, D. W., and X. P. Zhang. Laser cladding of stainless steel with $\mathrm{Ni}-\mathrm{Cr}_{3} \mathrm{C}_{2}$ and $\mathrm{Ni}$-WC for improving erosive-corrosive wear performance. Surface and Coatings Technology, Vol. 190, No. 2, 2005, pp. 212-217.

[22] Wilson, J. M., and Y. C. Shin. Microstructure and wear properties of laser-deposited functionally graded Inconel 690 reinforced with TiC. Surface and Coatings Technology, Vol. 207, No. 9, 2017, pp. 517-522.

[23] Jiang, D., C. Hong, M. Zhong, M. Alkhayat, A. Weisheit, A. Gasser,et al. Fabrication of nano-TiCp reinforced Inconel 625 composite coatings by partial dissolution of micro-TiCp through laser cladding energy input control. Surface and Coatings Technology, Vol. 249, No. 7, 2014, pp. 125-131.

[24] Shen, M. Y., X. J. Tian, D. Liu, H. B. Tang, and X. Cheng. Microstructure and fracture behavior of TiC particles reinforced Inconel 625 composites prepared by laser additive manufacturing. Journal of Alloys and Compounds, Vol. 734, 2018, pp. 188-195.

[25] Xu, X., G. Y. Mi, L. D. Xiong, P. Jiang, X. Y. Shao, and C. Wang. Morphologies, microstructures and properties of TiC particle reinforced Inconel 625 coatings obtained by laser cladding with wire. Journal of Alloys and Compounds, Vol. 740, 2018, pp. 16-27.

[26] Ikeno, S., K. Furuta, and K. J. Matsuda. Effect of alumina particle size on aging in Al203/Al-Cu-Mg composite materials. J. JPN. I.
MET, Vol. 45, No. 5, 1995, pp. 249-252.

[27] Meng, Q. W., L. Geng, and B. Y. Zhang. Laser cladding of Ni-base composite coatings onto Ti-6Al-4V substrates with pre-placed $\mathrm{B}_{4} \mathrm{C}+\mathrm{NiCrBSi}$ powders. Surface and Coatings Technology, Vol. 200, No. 16-17, 2006, pp. 4923-4928.

[28] Rajab, F. H., Z. Liu, and L. Li. Production of stable superhydrophilic surfaces on $316 \mathrm{~L}$ steel by simultaneous laser texturing and $\mathrm{SiO}_{2}$ deposition. Applied Surface Science, Vol. 427, 2018, pp. 1135-1145.

[29] Lu, W. J., D. Zhang, X. N. Zhang, R. J. Wu, T. Sakata, and H. Mori. Microstructure and tensile properties of in situ (TiB+TiC)/Ti (Tib:TiC=1:1) composites prepared by common casting technique. Materials Science and Engineering A, Vol. 311, No. 1-2, 2001, pp. 142-150.

[30] Du, J. N., G. Dong, Q. L. Deng, and J. H. Yao. Microstructure and properties of laser clad $\mathrm{NbC} / \mathrm{Ni} 60$ alloy composite coating. $\mathrm{Ap}$ plied Laser, No. 4, 2012, pp. 277-281.

[31] Niu, X., M. J. Chao, W. L. Wang, B. Yuan, and E. J. Liang. In situ synthesized $\mathrm{NbC}$ particulate reinforced $\mathrm{Ni}$-based composite coatings by laser cladding. Chinese Journal of Lasers, Vol. 33, No. 7, 2006, pp. 987-992.

[32] Cao, Y. B., S. X. Zhi, Q. Gao, X. T. Tian, T. Geng, X. Guan, et al. Formation behavior of in-situ $\mathrm{NbC}$ in Fe-based laser cladding coatings. Materials Characterization, Vol. 119, 2016, pp. 159165.

[33] Wu, X. L. In situ formation by laser cladding of a TiC composite coating with a gradient distribution. Surface and Coatings Technology, Vol. 115, No. 2-3, 1999, pp. 111-115.

[34] Chao, M. J., W. L. Wang, E. J. Liang, and D. Ouyang. Microstructure and wear resistance of $\mathrm{TaC}$ reinforced $\mathrm{Ni}$-based coating by laser cladding. Surface and Coatings Technology, Vol. 202, No. 10, 2008, pp. 1918-1922.

[35] Moghaddam, E. G., N. Karimzadeh, N. Varahram, and P. Davami. Impact-abrasion wear characteristics of in-situ VC-reinforced austenitic steel matrix composite. Materials Science and Engineering A, Vol. 585, No. 22, 2013, pp. 422-429.

[36] Zhao, G. L., C. Z. Huang, H. L. Liu, B. Zou, H. T. Zhu, and J. Wang. Preparation of in-situ growth $\mathrm{TaC}$ whiskers toughening $\mathrm{Al}_{2} \mathrm{O}_{3}$ ceramic matrix composite. International Journal of Refractory Metals \& Hard Materials, Vol. 36, 2013, pp. 122-125.

[37] Wang, Z. T., X. H. Zhou, and G. G. Zhao. Microstructure and for-

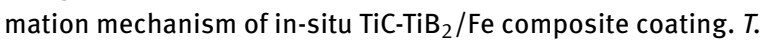
Nonferr. Metal. Soc, Vol. 18, No. 4, 2008, pp. 831-835.

[38] Li, M., J. Huang, Y. Y. Zhu, and Z. G. Li. Effect of heat input on the microstructure of in-situ synthesized TiN-TiB/Ti based composite coating by laser cladding. Surface and Coatings Technology, Vol. 206, No. 19-20, 2012, pp. 4021-4026.

[39] Liu, K., Y. J. Li, J. Wang, and Q. S. Ma. Effect of high dilution on the in situ synthesis of $\mathrm{Ni}-\mathrm{Zr} / \mathrm{Zr}-\mathrm{Si}(\mathrm{B}, \mathrm{C})$ reinforced composite coating on zirconium alloy substrate by laser cladding. Materials \& Design, Vol. 87, 2015, pp. 66-74.

[40] Wu, W. T., Y. Zhang, and B. H. Song. Effect of niobium on Microstructure and wear resistance of $\mathrm{Ni} 60$ laser cladding layer. Journal of Shijiazhuang Tiedao University, Vol. 30, No. 2, 2017, pp. 105-110.

[41] Cheng, Y., G. Dong, and G. X. Chen. Effect of niobium on microstructure and microhardness of laser clad nickel based alloy. Materials for Mechanical Engineering, Vol. 38, No. 9, 2014, pp. 24-28. 
[42] Hu, Y. L., X. Lin, X. B. Yu, J. J. Xu, M. Lei, and W. D. Huang. Effect of $\mathrm{Ti}$ addition on cracking and microhardness of Inconel 625 during the laser solid forming processing. Journal of Alloys and Compounds, Vol. 711, 2017, pp. 267-277.

[43] Ma, Q. S., Y. J. Li, and J. Wang. Effects of Ti addition on microstructure homogenization and wear resistance of wide-band laser clad $\mathrm{Ni60/WC}$ composite coatings. International Journal of Refractory Metals \& Hard Materials, Vol. 64, 2017, pp. 225-233.

[44] Yang, L. Q., Z. Y. Li, Y. Q. Zhang, S. Z. Wei, and F. Q. Liu. Al-TiC in situ composite coating fabricated by low power pulsed laser cladding on AZ91D magnesium alloy. Applied Surface Science, Vol. 435, 2018, pp. 1187-1198.

[45] Xiang, H., Y. Xu, L. Zhang, and L. Cheng. Synthesis and microstructure of tantalum carbide and carbon composite by liquid precursor route. Scripta Materialia, Vol. 55, No. 4, 2006, pp. 339-342.
[46] Yu, T., Q. L. Deng, G. Dong, and J. G. Yang. Effects of Ta on microstructure and microhardness of Ni based laser clad coating. Applied Surface Science, Vol. 257, No. 11, 2011, pp. 5098-5103.

[47] Zhao, N., L. Tao, H. Guo, and M. Q. Zhang. Microstructure and wear resistance of laser cladded $\mathrm{Ni}$-based coatings with nanometer $\mathrm{La}_{2} \mathrm{O}_{3}$ addition. Rare Metal Materials and Engineering, Vol. 46, No. 8, 2017, pp. 2092-2096.

[48] Wang, C. L., Y. Gao, Z. C. Zeng, and Y. K. Fu. Effect of rare-earth on friction and wear properties of laser cladding Ni-based coatings on 6063Al. Journal of Alloys and Compounds, Vol. 727, 2017, pp. 278-285. 